PROCEEDINGS OF THE UNITED STATES NATIONAL MUSEUM

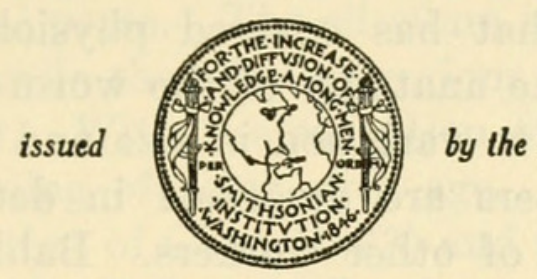

SMITHSONIAN INSTITUTION

U. S. NATIONAL MUSEUM

\title{
AN ANATOMICAL STUDY OF THE PEREGRINE MEGASCO. LECID EARTHWORM PHERETIMA HUPEIENSIS IN THE EASTERN UNITED STATES ${ }^{1}$
}

\section{By William C. Grant, Jr. ${ }^{2}$}

Pheretima (Perichaeta) hupeiensis was first described by Michaelsen (1895) from a specimen collected at Shi-hui-yao near Wuchang, Hupei Province, China. Since then the species has been recorded from a number of localities in China, Korea, and Manchuria. The first verified report of $P$.'hupeiensis in the United States is given by Chen (1933) from a specimen collected at Philadelphia, Pa.

Gates (1935) reports that the species was discovered by Dr. W. R. Walton of the U. S. Department of Agriculture on a golf course near Catonsville, Md., in 1935. A specimen collected at Washington, D. C., is also reported by Gates. Numerous reports from golf links in the mid-1930's of an exotic earthworm were probably concerned with $P$. hupeiensis. Its outbreak in Westchester County, N. Y., and in Fairfield County, Conn., initiated a control program by the Connecticut Agriculture Experiment Station, as the large number of castings deposited by the worms on golf greens of the area was becoming a serious problem. Chen (1933) suggests that the species

1 Representing a portion of a dissertation submitted in partial fulfillment of the requirements for the degree of Doctor of Philosophy at Yale University.

Department of Zoology, Dartmouth College,'Hanover, N. H. 
was introduced into the United States in shipments of nursery stock, and Schread (1952) believes that human agency alone can account for its present distribution through the medium of turf transports from one golf course to another.

The anatomical study presented here represents the first phase of an investigation that has covered physiological and ecological problems as well. The anatomy of the worm has been reexamined with special reference to variation in size and form, and only those morphological characters are described in detail where they vary from the descriptions of other workers. Bahl's (1950) memoir on the Indian earthworm Pheretima posthuma has been an extremely valuable reference. Specimens of $P$. hupeiensis used in the present study have been deposited in the U. S. National Museum, Washington, D. C.

Appreciation is expressed to Dr. Roger B. Friend, Dr. G. E. Pickford, and Prof. G. E. Hutchinson for their counsel during the course of this study.

Methods: All measurements and dissections were made on specimens swept from the greens of the Pelham Country Club, Pelham, N. Y., on July 7, 1949, or on specimens collected from the nursery plot at the same location on various occasions between July and October 1952. Because of the differential contractility of anesthetized individuals, all measurements of width and length were made on specimens preserved in the field in 4 percent formalin, in which it was hoped that the degree of contraction would be uniform. Widths were taken with calipers to the nearest $0.5 \mathrm{~mm}$. in the region of the worm just posterior to the male pores and genital papillae.

Before sectioning in the laboratory the animals were kept on damp cheesecloth or in aerated tap water for several days in order to allow evacuation of the gut. Worms were then fixed in Petrunkevitch's sublimate fluid for 24 hours, sectioned, and stained with hematoxylin and eosin. Whole mounts of spermathecae, prostates, etc., were made of organs fixed in Petrunkevitch's fluid and cleared in amylacetate. In order to examine the internal sexual structures it was necessary to reverse the normal procedure and dissect worms from the ventral side.

Before analysis all specimens to be examined were placed in the following categories:

1. Mature. Clitellum fully developed.

2. Semimature. Clitellar segments distinct but with all setae and dorsal pores still visible.

3. Immature. Clitellar segments not differentiated. Male pores and genital papillae well developed.

4. Juvenile. No differentiation of clitellar segments and with male pores and genital papillae lacking or indistinct. 
CoLor: Pheretima hupeiensis varies in life from pale green to deep olive. Occasionally it is of a deeper hue anteriorly, although this is by no means a characteristic condition. A distinct purple or black line is apparent on the dorsal midline extending from the posterior margin of the clitellum to the last segment, interrupted intersegmentally by the dorsal pores. The clitellum in the mature condition is a brilliant ivory, while the clitellar regions of the semimature are almost black in color. With the exception of the clitellum there is apparently no deepening of color with age. This description is in near agreement with that of Chen (1933) and that of Schread (1952). The specimens from the Pelham collection seldom showed the pronounced difference in coloration from the dorsal to ventral surfaces as described by Chen for worms of the Yangtze Valley, China. His description of animals with a light chocolate clitellum was probably of individuals past their sexual prime, as this color is quite common just before clitellar degeneration.

SizE: In the preserved specimens from Pelham, the size varies from 89 to $22 \mathrm{~mm}$. in length, and from 5.5 to $1 \mathrm{~mm}$. in width. The mean lengths and widths for each of the four categories described above and their standard deviations are shown in table 1 . The relationship between length and width is presented graphically in figure 1. The line representing the regression of width on length indicates a constant isometric relationship between length and diameter. In the equation $\mathrm{W}=a+b \mathrm{~L}$ the values of the constants $a$ and $b$ are 0.18 and 0.058 , respectively. The correlation coefficient of 0.77 is highly significant. The analysis justifies the earlier assumption that worms preserved under standard conditions are uniformly contracted.

In specimens from Szechwan Province, China, Chen (1931) gives a size range from 70 to $130 \mathrm{~mm}$. in length, and 3 to $6 \mathrm{~mm}$. in diameter, while his 1933 Yangtze Valley description mentions worms as long as $222 \mathrm{~mm}$. Kobayashi (1938) gives lengths of 61 to $150 \mathrm{~mm}$. with widths up to $5 \mathrm{~mm}$. in specimens from Korea. The type specimen described by Michaelsen (1895) from Hupei Province, China, measured $40 \mathrm{~mm}$. in length with a diameter of $3.5 \mathrm{~mm}$. A specimen described by Gates (1935) from Washington, D. C., was $70 \mathrm{~mm}$. long and $3 \mathrm{~mm}$. wide.

It would be extremely difficult to draw any definite conclusions from these figures, for, with the exception of Gates' specimen it is not known under what conditions the worms were measured, nor is there an indication of their state of maturity. Nevertheless, there is some indication that on the Asiatic mainland the species is larger than the peregrine population of the United States. The relation of width to length suggests that the figures of Chen and Kobayashi show worms 
in a greater state of attenuation than my formalin specimens. In order to obtain some idea of the differences the length-width relationship may be expressed in the form of an index $(w / 1 \times 100)$. Mean values for the Pelham population ranging from juvenile to mature are $6.2,6.2,5.8$, and 6.0. If the longest worm is correlated with the greatest diameter and the shortest with the smallest the following indices

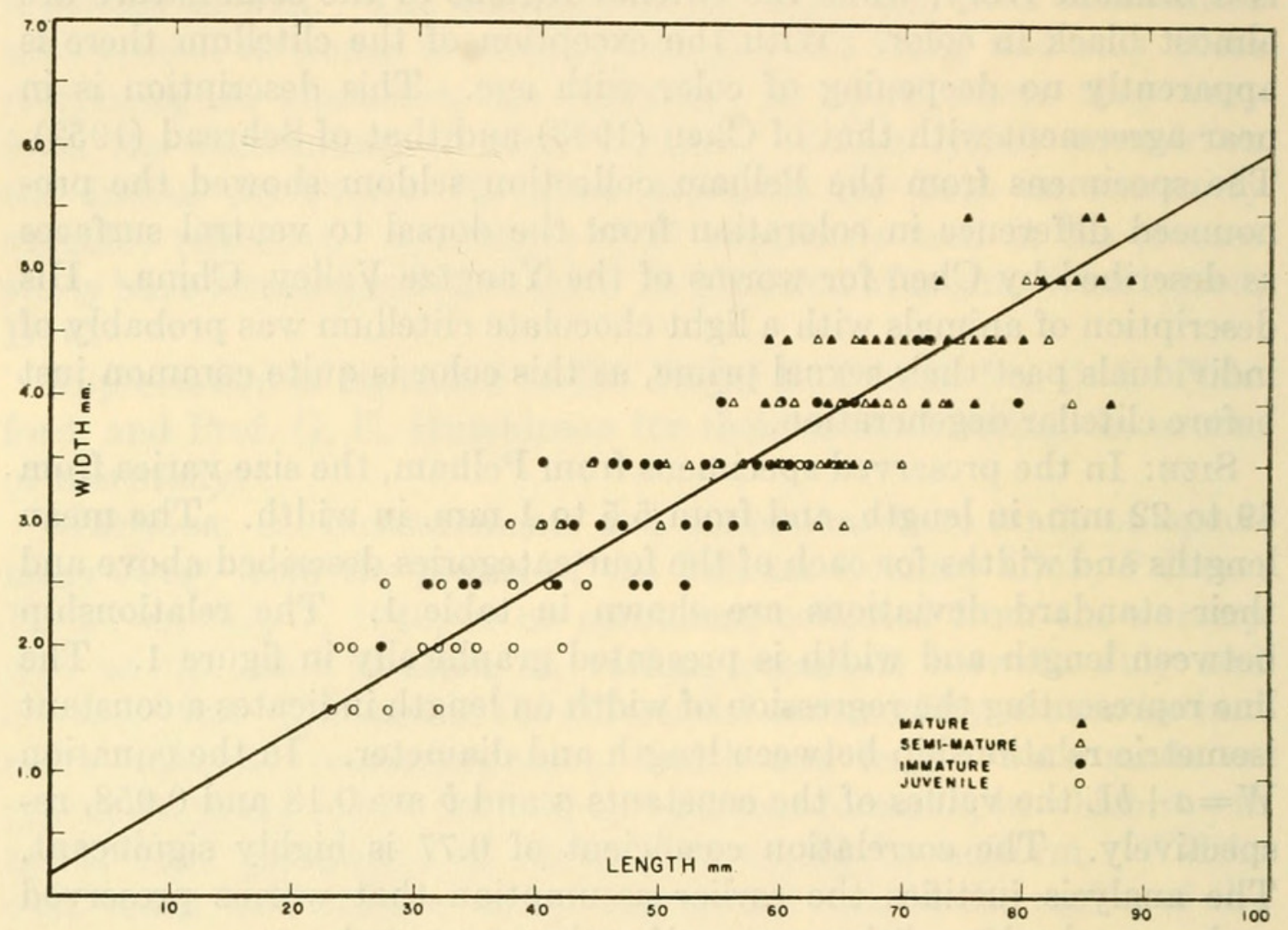

FigURE 1.-Relation of length to diameter in specimens of Pheretima hupeiensis preserved in 4 percent formalin.

are obtained for the Asiatic specimens: Chen 4.3-4.6, Kobayashi 3.3. These forms appear more slender than the Pelham stock.

Avel (1929) has shown that size variation in Allolobophora is dependent on nutrition, and Pickford (1937) says that because of this factor it would be impossible to indicate a size range for a species that would have taxonomic significance. This is further substantiated by the apparent larger size of the oriental population of $P$. hupeiensis.

WeIght: A group of 162 worms collected from the nursery plot at Pelham on Aug. 22, 1952, were classified into the four categories of maturity and weighed. The range was from $898 \mathrm{mg}$. for a mature worm to $41 \mathrm{mg}$. for a juvenile. The means and their standard deviations are listed in table 1. The mean value for juveniles is $103 \mathrm{mg}$., with no weights above $223 \mathrm{mg}$. being recorded for this category. It is probable that somewhere between these values the majority of the population will develop prominent male papillae. The figures for 
mature individuals give a mean of $562 \mathrm{mg}$. with a minimum weight of $302 \mathrm{mg}$., and it is between these values that most worms become fully clitellate. As the semimature and immature categories are continually shifting, it would be difficult to analyze them satisfactorily unless weights were taken at frequent intervals from population samples distributed over a period of several years. Such a project is very important, but would have to be carried out on a more readily available species of worm than $P$. hupeiensis, which has been subjected to routine extermination over its recorded range in the United States.

Segments: Michaelsen (1895) described P.hupeiensis as having 129 segments and again (1899) as having segments ranging in number from 119 to 132 . Chen (1933) gives numbers from 110 to 128, and Kobayashi (1938) indicates a range of 97 to 132 for his Korean collections. Counts made on preserved material from the Pelham collection show no correlation between the degree of sexual maturity and number of segments. The average for 22 juveniles was 125 segments, and for 39 adults it was 126 , with a range of 119 to 130 for the entire series studied.

The whole problem of whether or not earthworms continue adding segments during life has been discussed by Gates (1948). After a study of a number of megascolecid, lumbricid, and glossoscolecid species he concludes that postembryonic growth generally involves the production of new segments, although segment production does not take the same form in every case nor is it uniform throughout the three families. Because no specimen of $P$. hupeiensis has been found to date that can definitely be regarded as newly hatched, it is impossible to state whether new segments are added after hatching. However, since juveniles and fully mature specimens possess about the same number of segments, few if any additions are made after the worms have attained a length of $35 \mathrm{~mm}$. Careful dissection of juvenile specimens in the region of the anal segment revealed nothing that suggested that this segment was not fully differentiated.

Setae: The numerous setae, which are weakly sigmoid in shape and about $0.2 \mathrm{~mm}$. in length, are perichaetous, as each segment has an equatorial band of setae passing around it. Michaelsen found 72 setae on segment 25, and Chen (1933) gives numbers ranging from 68 to 88 for the same segment with 14 to 22 between the spermathecal pores of segment 8 and 10 to 16 between the male pores on segment 18 . Gates (1935) records 85 setae on segment 20 , and 18 on segment 18 between the male pores.

In the specimens of $P$. hupeiensis in the Pelham collection, setal numbers averaged about 8 between the spermathecal pores of segment 8 , with a range from 4 to $13 ; 12$ between the male pores of segment 18 , 
with a range of 8 to 16 ; and 79 around the circumference of segment 30 , with a range of 74 to 84 (table 1). In mature specimens a few setae were usually seen on the ventral surface of the clitellum. The wide range in setal number is due in part to the fact that setae are continually being lost and replaced.

Prostomium: The small prostomium overhangs the mouth and is epilobous, according to the terminology of Stephenson (1930), in that it is well subdivided from, but with its posterior portion extending into, segment 1 . In preserved specimens the prostomium is withdrawn and not easily examined.

DoRsal poRes: In 39 mature specimens collected at Pelham the first dorsal pore appeared on intersegmental furrow 11/12 and, in all observations made since, this has been found to be a very constant character. Michaelsen $(1895,1899)$ notes the first dorsal pore on intersegmental furrow 12/13, as does Gates (1935). However, Chen (1931, 1933) and Gates (1939) record the first dorsal pore on 11/12. Dorsal pores are present in the dorsal midline at all intersegmental furrows beginning with $11 / 12$ in the Pelham specimens, although they may be obscured in furrows $14 / 15$ and $15 / 16$ by the clitellum.

It is through the dorsal pores that coelomic fluid is ejected when the worm is irritated. In $P$. hupeiensis the peculiarly pungent odor of the coelomic fluid, described by Gates (1935) as being similar to that of "carrots freshly dug," is an important diagnostic character.

Male Reproductive system: The male reproductive system is holandric. Paired testes are situated in segments 10 and 11 , attached to the posterior face of septa $9 / 10$ and 10/11 close to the ventral nerve cord and directly in front of their corresponding spermiducal funnels. The latter have highly folded, ciliated margins, each passing immediately into a vas deferens in the following segment. Two pairs of large seminal vesicles are located in segments 11 and 12 , probably arising as

\begin{tabular}{|c|c|c|}
\hline & AbBREVIATIONS USED ON FIGURES & \\
\hline 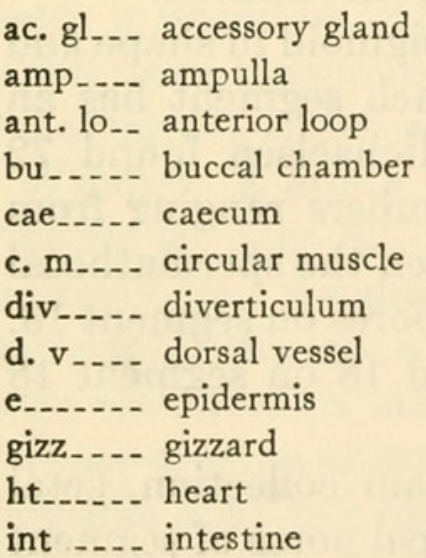 & 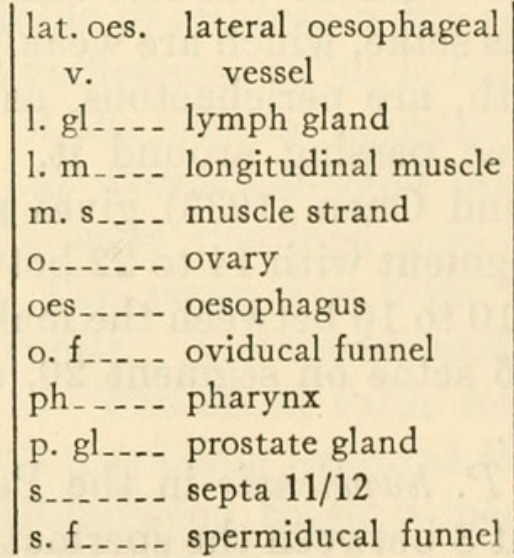 & \begin{tabular}{|l} 
sp..... \\
su.
\end{tabular} \\
\hline
\end{tabular}


septal pouches from septa 10/11 and 11/12. Each communicates directly with and receives the spermatozoa of the segment in front. The seminal vesicles when full of developing sperm are large and distended, passing dorsally around the gut to the dorsal blood vessel.

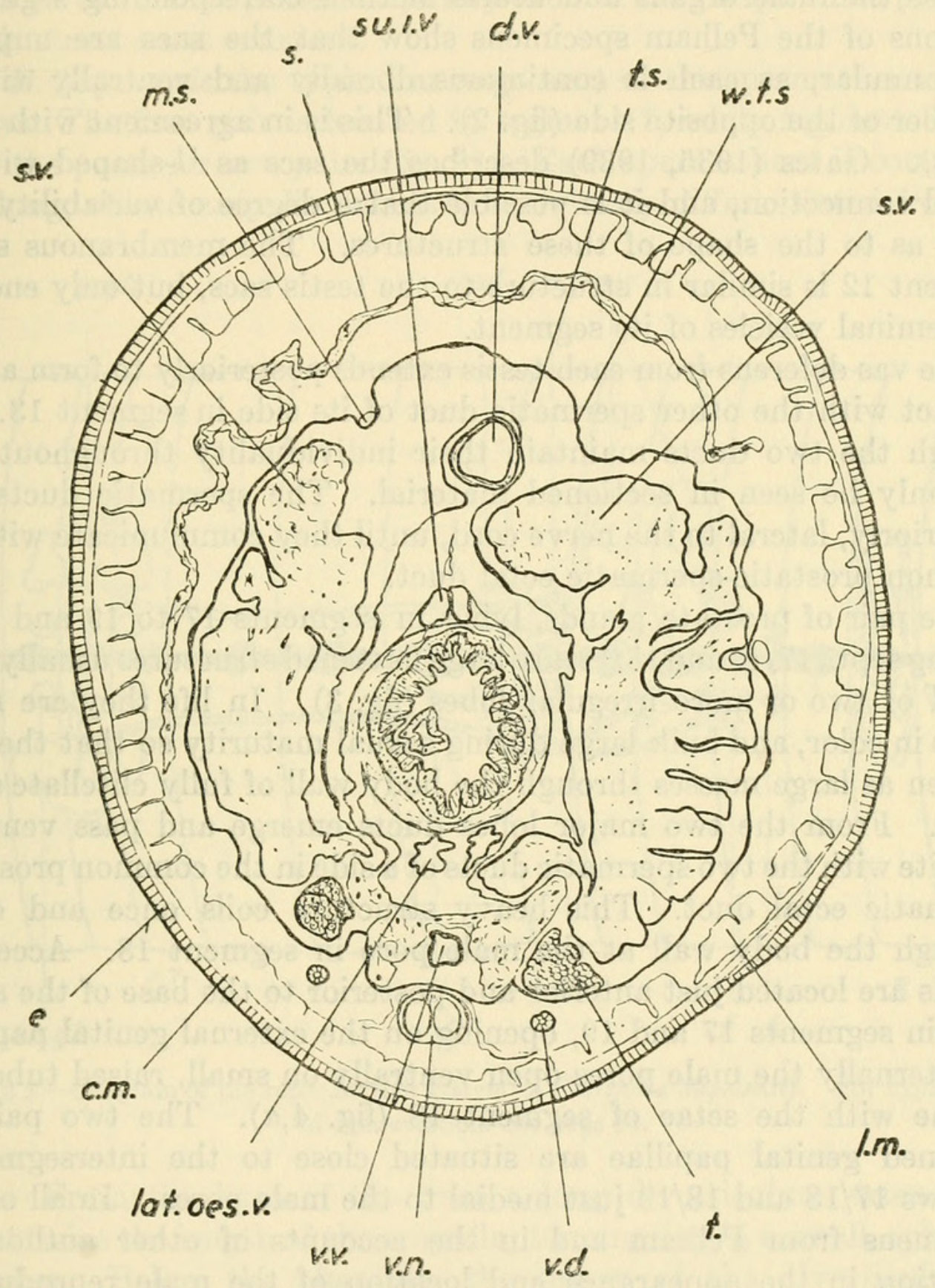

Figure 2.-Pheretima hupeiensis; semidiagrammatic view of a section through segment 11 showing the annular shape of the testes sacs. For explanation of abbreviations see facing page.

The small, narrow vesicles described by Chen (1933) were undoubtedly not seasonally mature or had been shrunk during preservation.

In $P$. hupeiensis the testes, funnels, and seminal vesicles of segments 10 and 11 and the seminal vesicles of segment 12 are partitioned from the coelomic cavity by large, thin-walled sacs. These are commonly called testis sacs, but Kobayashi (1938) has questioned the propriety 
of calling the posterior sac by this name as there are no testes present in segment 12 . He proposes terming this structure a "membranous sac." The testis sacs of segments 10 and 11 are very large, extending laterally almost to the body wall and medially to the esophagus to enclose the male organs and hearts of their corresponding segments. Sections of the Pelham specimens show that the sacs are unpaired and annular, as each is continuous dorsally and ventrally with its member of the opposite side (fig. 2). This is in agreement with Chen (1933). Gates $(1935,1939)$ describes the sacs as U-shaped with no dorsal connection, and it is possible that a degree of variability may exist as to the shape of these structures. The membranous sac of segment 12 is similar in structure to the testis sacs, but only encloses the seminal vesicles of its segment.

The vas deferens from each testis extends posteriorly to form a close contact with the other spermatic duct of its side in segment 13 . Although the two ducts maintain their individuality throughout, this can only be seen in sectioned material. The spermatic ducts pass posteriorly, lateral to the nerve cord, until they communicate with the common prostatic-spermatic ectal duct.

The pair of prostate glands, lying in segments 17 to 19 and penetrating septa $17 / 18$ and $18 / 19$, are large flattened structures usually composed of two or more irregular lobes (fig. 3). In life they are milky white in color, and bulk large during sexual maturity so that they can be seen as large masses through the body wall of fully clitellate specimens. From the two major lobes ducts emerge and pass ventrally to unite with the two spermatic ducts of a side in the common prostaticspermatic ectal duct. This heavy structure coils once and opens through the body wall at the male pore in segment 18. Accessory glands are located just anterior and posterior to the base of the above duct in segments 17 and 19, opening on the external genital papillae.

Externally the male pores open ventrally on small, raised tubercles in line with the setae of segment 18 (fig. 4,a). The two pairs of flattened genital papillae are situated close to the intersegmental furrows $17 / 18$ and $18 / 19$ just medial to the male pores. In all of the specimens from Pelham and in the accounts of other authors no variation in the appearance and location of the male reproductive organs, with the exception of the testis sacs, has been noted.

Female reproductive system: The ovaries are situated on the posterior face of septum 12/13 just lateral to the ventral nerve cord. They are white in color and are composed of a large number of digital processes arranged so as to resemble a fan. The paired oviducal funnels are large, convoluted structures in segment 13 facing the ovaries and communicating posteriorly with the short oviducts that pass through the body wall in segment 14 to the single female pore 
(fig. 3). This pore opens on a raised circular papilla in the ventral midline of segment 14 just posterior to intersegmental furrow 13/14 (fig. $4, a$ ).

The clitellum consists of a smooth, slightly swollen girdle in segments 14 to 16 that passes uniformly around the body. The position of this structure is constant.

In $P$. hupeiensis the typical arrangement of the spermathecae is as follows: The first pair is located in segment 7, while segment 8 contains the posterior two pairs (fig. 3). Each spermatheca is composed of a long, oblate ampulla, which is not clearly differentiated from its
v.n. p.gl.
o.f. o. s.v.

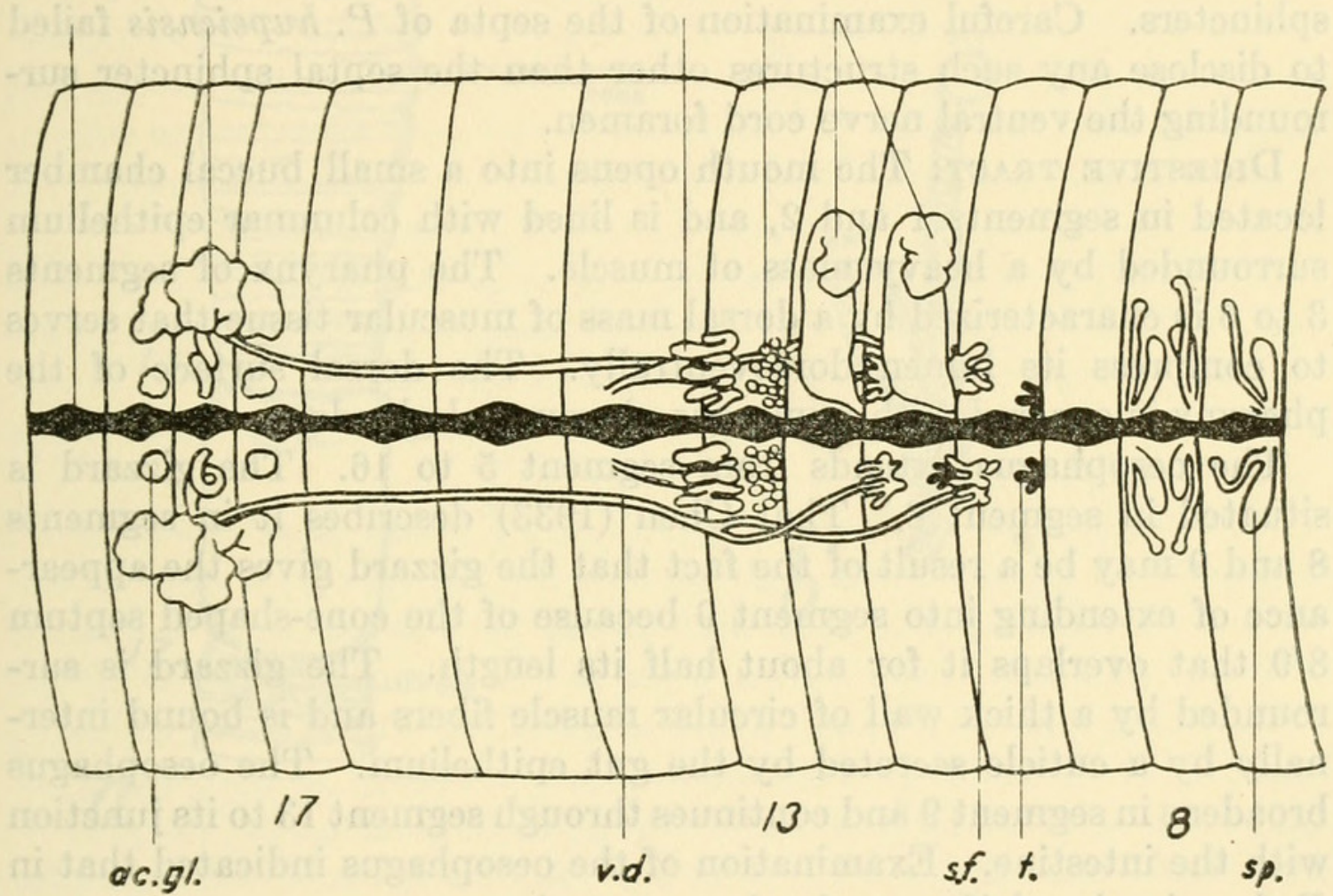

FIGURE 3.-Diagram of the reproductive system of Pheretima hupeiensis. For explanation of abbreviations see page 54 .

duct. From the base of the duct a long diverticulum extends for about twice the length of the ampulla, terminating in a small, spherical chamber. Below the chamber, the lumen of the diverticulum is highly convoluted for about half its length before it straightens into a tube leading directly to the duct of the ampulla (fig. 4,b). The spermathecae described by Chen (1933) as spatulate and highly wrinkled were obviously in a collapsed condition.

Although many animals show the typical arrangement described above, it is quite common to find individuals with an entire spermatheca transferred to an adjacent segment. However, no more nor less than three pairs of spermathecae have been described in a single 
specimen. The external order of the spermathecal pores, which are located by pairs just posterior to the intersegmental furrows $6 / 7,7 / 8$, and $8 / 9$ on either side of the ventral midline, is constant regardless of internal conditions (fig. 4,a). Michaelsen (1895) noted only two pairs of spermathecae in the type from Hupei Province, but in 1899 he redescribed the specimen as possessing three pairs. No variation in the spermathecal number has been described by other investigators.

SEPTA: Only the first three septa are lacking in $P$. hupeiensis. Septum $4 / 5$ is extremely fine, while septa $5 / 6$ to $8 / 9$ are heavy and muscular as are those of the genital segments, but to a lesser extent. Bahl (1950) noted that in Pheretima posthuma all septa past 14/15 are perforated by numerous small apertures surrounded by muscular sphincters. Careful examination of the septa of $P$. hupeiensis failed to disclose any such structures other than the septal sphincter surrounding the ventral nerve cord foramen.

Digestive tract: The mouth opens into a small buccal chamber located in segments 1 and 2, and is lined with columnar epithelium surrounded by a heavy mass of muscle. The pharynx of segments 3 to 5 is characterized by a dorsal mass of muscular tissue that serves to compress its lumen dorsoventrally. The dorsal surface of the pharynx is covered with numerous pharyngeal glands.

The oesophagus extends from segment 5 to 16 . The gizzard is situated in segment 8 . That Chen (1933) describes it in segments 8 and 9 may be a result of the fact that the gizzard gives the appearance of extending into segment 9 because of the cone-shaped septum $8 / 9$ that overlaps it for about half its length. The gizzard is surrounded by a thick wall of circular muscle fibers and is bound internally by a cuticle secreted by the gut epithelium. The oesophagus broadens in segment 9 and continues through segment 13 to its junction with the intestine. Examination of the oesophagus indicated that in $P$. hupeiensis calciferous glands are wanting.

The intestine occupies the entire length of the worm beyond septum $13 / 14$ to the terminal anus (fig. 4,c). A pair of simple intestinal caeca appear as lateral projections of the intestinal wall in segment 27 , although a few cases observed had the caecum originating in segment 28. Those of the type are located in segment 26 .

Hearts: The paired lateral hearts are located in segments 10 to 13 (fig. 4,c). The hearts of segment 10 are very stout and lack commissural connections to the supraintestinal blood sinus. The following three pairs join the dorsal and ventral blood vessels and have commissural connectives with the blood sinus of segments 11 to 13 , and may be termed lateral-oesophageal hearts to differentiate them from the simple lateral hearts of segment 10 according to Bahl (1921). In 
segment 9 a pair of heavy but nonpulsating vessels connect the supraintestinal blood vessel with the lateral-oesophageal vessels on each side. Two pairs of similar vessels occurring in segments 10 and 11 of Pheretima posthuma are termed "anterior-loops" by Bahl (1921).

ExCRETORy System: The excretory system is similar to that of $P$. posthuma described by Bahl $(1921,1950)$. The system is meronephric in that it is composed of several types of nephridia, and that

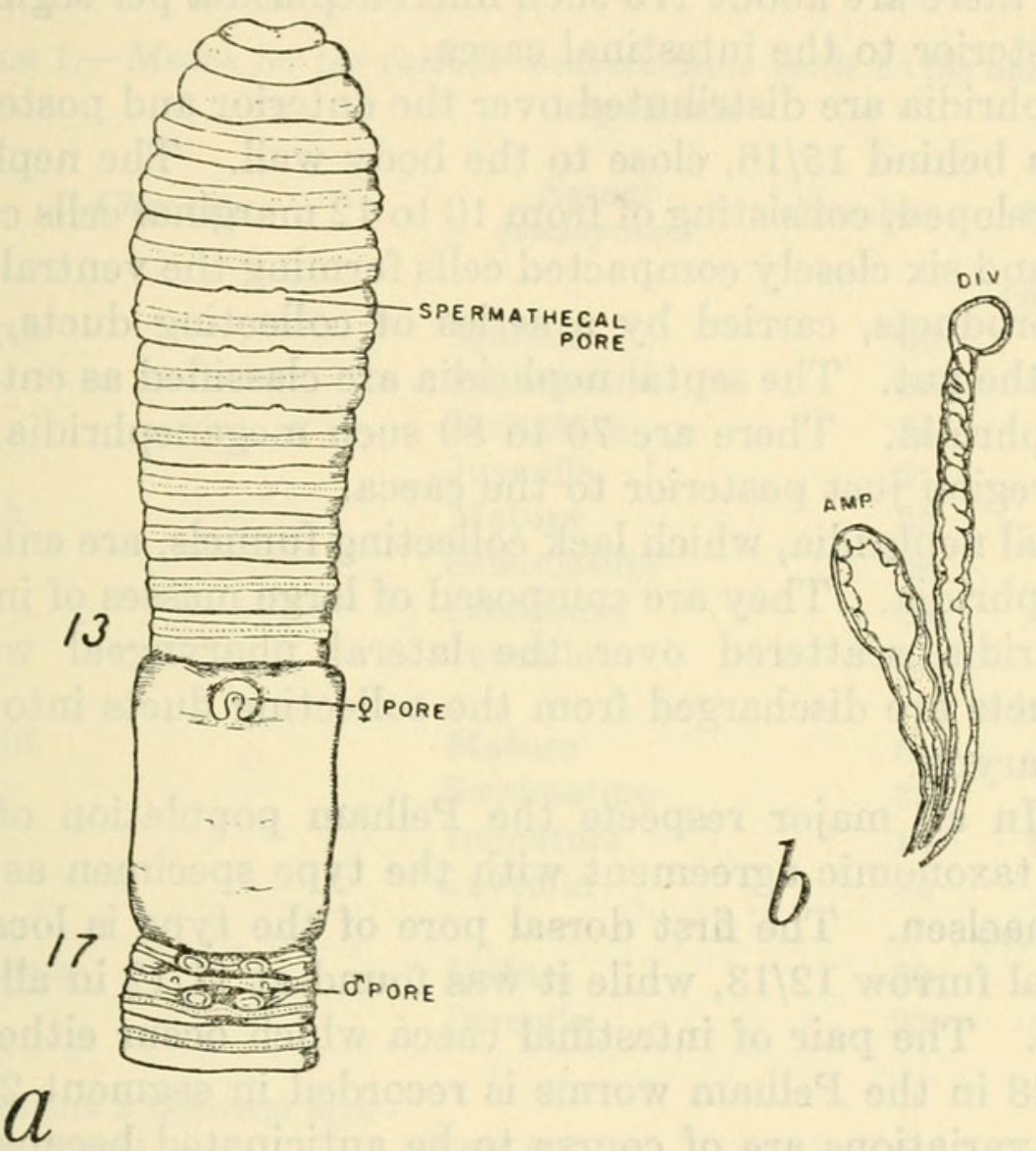

bu. ph.

gizz.

int. d.v.

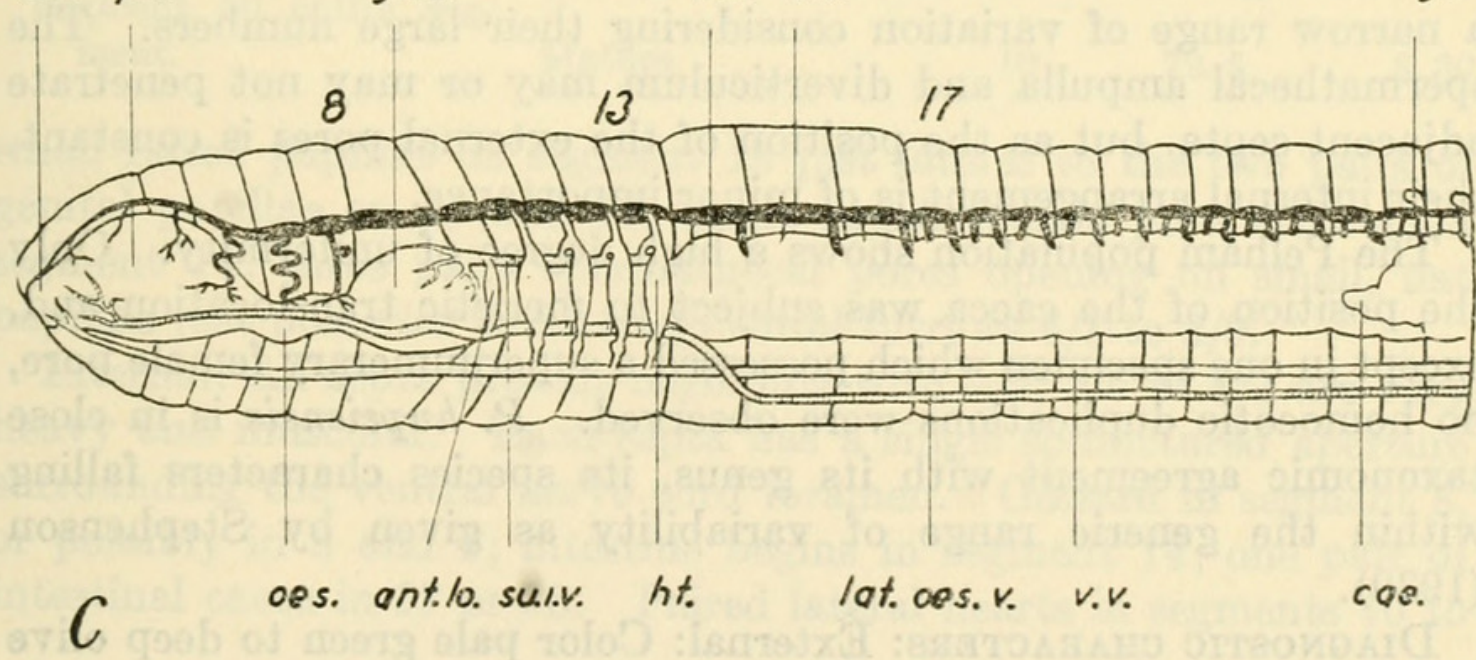

FigURE 4.-Pheretima hupeiensis: $a$, external sexual characters; $b$, a spermatheca; $c$, digestive system and hearts. For explanation of abbreviations see page 54 . 
numerous nephridia are present in most segments. The following classification follows that of Bahl (1924, 1926, 1950).

The integumentary nephridia are extremely small, ranging from $0.25-0.5 \mathrm{~mm}$. in length, and are scattered over the interior face of the body wall in all but the first two segments. As no collecting funnel is present and each nephridium communicates directly to the exterior through its nephridiopore, they are termed exonephric micronephridia. In $P$. hupeiensis there are about 175 such micronephridia per segment in the region posterior to the intestinal caeca.

The septal nephridia are distributed over the anterior and posterior faces of all septa behind 15/16, close to the body wall. The nephrostome is well developed, consisting of from 10 to 12 marginal cells composing a funnel and six closely compacted cells forming the ventral lip. The excretory products, carried by a series of collecting ducts, are discharged into the gut. The septal nephridia are classified as enteronephric meganephridia. There are 70 to 80 such meganephridia per segment in the region just posterior to the caeca.

The pharyngeal nephridia, which lack collecting funnels, are enteronephric micronephridia. They are composed of large masses of interconnected nephridia scattered over the lateral pharyngeal walls. Excretory products are discharged from the collecting ducts into the lumen of the pharynx.

Discussion: In all major respects the Pelham population of $P$. hupeiensis is in taxonomic agreement with the type specimen as described by Michaelsen. The first dorsal pore of the type is located at intersegmental furrow $12 / 13$, while it was found at $11 / 12$ in all the Pelham animals. The pair of intestinal caeca which occur either in segment 27 or 28 in the Pelham worms is recorded in segment 26 of the type. Size variations are of course to be anticipated because of nutritional differences, etc., as is the relation between absolute size and the degree of sexual maturity. Segment and setal numbers show a narrow range of variation considering their large numbers. The spermathecal ampulla and diverticulum may or may not penetrate adjacent septa, but as the position of the external pores is constant, their internal arrangement is of minor importance.

The Pelham population shows a high degree of uniformity. Only the position of the caeca was subject to meristic translocation and, except in one specimen which possessed a supernumerary female pore, no homoeotic duplications were observed. P. hupeiensis is in close taxonomic agreement with its genus, its species characters falling within the generic range of variability as given by Stephenson (1930).

Diagnostic characters: External: Color pale green to deep olive with a distinct purple or black line on the dorsal midline extending from the posterior margin of the clitellum to the anal segment. 
Preserved animals are light gray and the dorsal line is seldom discernible. Odor pungent. Length 40 to $222 \mathrm{~mm}$.; diameter 1 to 6 mm.; weight 320 to $898 \mathrm{mg}$.; segments 97 to 138 in number. First dorsal pore on intersegmental furrow 11/12 and 12/13. Prostomium small and epilobous. Perichaetous, the setae varying in number from 4 to 22 between the spermathecal pores on segment $8 ; 8$ to 18 between the male pores on $18 ; 66$ to 88 on $25 ; 74$ to 84 on 30 . Clitellum smooth, white and annular on segments 14 to 16 . Male pores on

TABLE 1.-Means for the various measurements made on the anatomy of Pheretima hupeiensis

\begin{tabular}{|c|c|c|c|c|}
\hline Character & $\begin{array}{l}\text { Sexual } \\
\text { development }\end{array}$ & Number & $\begin{array}{l}\text { Mean } \\
(m m .)\end{array}$ & $\begin{array}{l}\text { Standard } \\
\text { deviation }\end{array}$ \\
\hline \multirow[t]{4}{*}{ Length } & Mature & 39 & 73. 2 & 7. 1 \\
\hline & Semimature & 46 & 67.2 & 10. 8 \\
\hline & Immature & 55 & 54. 8 & 10. 6 \\
\hline & Juvenile & 22 & 35.0 & 9.6 \\
\hline \multirow[t]{4}{*}{ Width } & Mature & 39 & 4. 4 & 1.1 \\
\hline & Semimature & 46 & 3. 9 & 1. 3 \\
\hline & Immature & 55 & 3. 4 & 1. 0 \\
\hline & Juvenile & 22 & $\begin{array}{l}2.2 \\
(m g .)\end{array}$ & 0.5 \\
\hline \multirow[t]{4}{*}{ Weight } & Mature & 61 & 562.0 & 135.6 \\
\hline & Semimature & 38 & 514. 1 & 139.6 \\
\hline & Immature & 18 & 276.8 & 89. 3 \\
\hline & Juvenile & 34 & $\begin{array}{r}103.5 \\
\text { (number) }\end{array}$ & 56.4 \\
\hline \multirow[t]{2}{*}{ Segments } & Mature & 39 & 126. 0 & 2. 6 \\
\hline & Juvenile & 20 & 125.3 & 2. 8 \\
\hline \multicolumn{5}{|l|}{ Setae } \\
\hline $\begin{array}{l}\text { Segment } 8 \text { between sper- } \\
\text { mathecal pores. } \\
\text { Segment } 18 \text { between male }\end{array}$ & Mature & 39 & 8. 7 & 2. 07 \\
\hline $\begin{array}{l}\text { pores. } \\
\text { Segment } 30 \text { entire seg- }\end{array}$ & Mature & 39 & 12. 0 & 2. 44 \\
\hline ment. & Mature & 10 & 79.5 & 3. 30 \\
\hline
\end{tabular}

small raised papillae on segment 18 just lateral to the two pairs of genital papillae on 17 and 19; single round female pore ventral on segment 14; three pairs spermathecal pores opening on small, flat papillae just posterior to intersegmental furrows $6 / 7$ to $8 / 9$.

Internal: All septa present beginning with $4 / 5 ; 5 / 6$ to $8 / 9$ are very heavy and muscular. Each septa has a single sphinctured aperture surrounding the ventral nerve cord foramen. Gizzard in segment 8, or possibly in 8 and 9 ; intestine begins in segment 14; one pair of intestinal caeca in 27 or 28 . Paired lateral hearts in segments 10 to 
13 , the pair in segment 10 being stout and lacking commissural connectives. Excretory system meronephric. Exonephric integumentary micronephridia in all but the first two segments; enteronephric meganephridia on all septa behind $15 / 16$; enteronephric micronephridia on the lateral walls of the pharynx. Male reproductive system holandric. Paired testes and spermiducal funnels in segments 10 and 11; paired seminal vesicles in segments 11 and 12 . Testes and funnels of segment 10 and testes, funnels, and seminal vesicles of segment 11 enclosed in large membranous testis sacs that may be annular or Ushaped. Seminal vesicles of segment 12 enclosed in a membranous sac. Prostate gland well developed in segments 17 to 19 , with a large coiled prostatic-spermatic ectal duct in segment 18; accessory glands small, located near end of duct in segments 17 and 19 . One pair of ovaries and oviducal funnels in segment 13. Internal arrangement of spermathecae variable; typically the first pair is located in segment 7 , while segment 8 contains the posterior two pairs. Spermathecal ampulla long and oblate; diverticulum twice the length of ampulla, its coiled duct terminating in a small round chamber.

TyPe: Perichaeta hupeiensis Michaelsen (1895), Hamburg Museum.

Summary: The anatomy of Pheretima hupeiensis Michaelsen, a megascolecid earthworm indigenous to the far east, has been redescribed on specimens collected in Westchester County, N. Y., where it occurs as a peregrine. A constant isometric relationship exists between length and width when worms are preserved under standard conditions. The population shows a high degree of uniformity. The only characters showing variation are the intestinal caeca, which may arise in segments 27 or 28 , and the spermathecae, which are constant in number but vary in their position relative to the adjacent septa. 


\section{Literature cited}

Avel, M.

1929. Recherches expérimentales sur les caractères sexuels somatique des lombriciens. Bull. Biol. France Belgique, vol. 63, p. 149.

BAHL, K. N.

1921. On the blood-vascular system of the earthworm Pheretima and the course of the circulation in earthworms. Quart. Journ. Micr. Sci., vol. 65 , pp. 349-393.

1924. On the occurrence of the "enteronephric" type of nephridial system in earthworms of the genus Lampite. Quart. Journ. Micr. Sci., vol. 68 , pp. 67-99.

1926. The enteronephric system in Woodwardia with remarks on the nephridia of Lampite dubius. Quart. Journ. Micr. Sci., vol. 70, pp. 113-134.

1950. Pheretima, the Indian earthworm, in The Indian zoological memoirs on Indian animal types, I (ed. by Bahl), ed. 4, $84 \mathrm{pp}$.

Chen, Y.

1931. On the terrestrial Oligochaeta from Szechuan. Contr. Biol. Lab. Sci. Soc. China, vol. 7, pp. 117-171.

1933. A preliminary survey of the earthworms of the lower Yangtze Valley. Contr. Biol. Lab. Sci. Soc. China, vol. 11, pp. 109-121.

Gates, G. E.

1935. New earthworms from China, with notes on the synonymy of some Chinese species of Drawida and Pheretima. Smithsonian Misc. Coll., vol. 93, No. 3, 19 pp.

1939. On some species of Chinese earthworms, with special reference to specimens collected in Szechwan by Dr. D. C. Graham. Proc. U. S. Nat. Mus., vol. 85 , pp. $405-507$.

1948. On segment formation in normal and regenerative growth of earthworms. Growth, vol. 12, pp. 165-180.

Kobayashi, S.

1938. Earthworms of Korea, I. Sci. Rep. Tohoku Teikoku Daigaku, ser. 4, vol. 8, pp. 89-170.

Michaelsen, W.

1895. Zur Kenntnis der Oligochaeten. Abh. Naturw. Hamburg, vol. 13, pp. 35-36.

1899. Terricolen von verschiedenen Gerbieten der Erde. Mitt. Naturh. Mus. Hamburg, vol. 16, pp. 6-8.

Pickford, G. E.

1937. The acanthodriline earthworms of South Africa, $612 \mathrm{pp}$.

Schread, J. C.

1952. Habits and control of the oriental earthworm. Connecticut Agr. Exp.

Stephenson, J.

Station Bull. No. 556, pp. 5-15.

1930. The Oligochaeta, $978 \mathrm{pp}$. 


\section{$2 \mathrm{BHL}$ Biodiversity Heritage Library}

Grant, William C. 1955. "An Anatomical Study of the Peregrine Megascolecid Earthworm Pheretima hupeiensis in the Eastern United States." Proceedings of the United States National Museum 105(3351), 49-63.

https://doi.org/10.5479/si.00963801.105-3351.49.

View This Item Online: https://www.biodiversitylibrary.org/item/53512

DOI: https://doi.org/10.5479/si.00963801.105-3351.49

Permalink: https://www.biodiversitylibrary.org/partpdf/52461

\section{Holding Institution}

Smithsonian Libraries

\section{Sponsored by}

Smithsonian

\section{Copyright \& Reuse}

Copyright Status: Public domain. The BHL considers that this work is no longer under copyright protection.

This document was created from content at the Biodiversity Heritage Library, the world's largest open access digital library for biodiversity literature and archives. Visit BHL at https://www.biodiversitylibrary.org. 